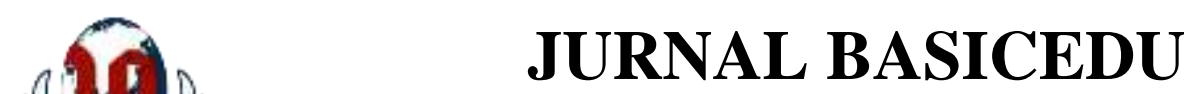

Volume 6 Nomor 1 Tahun 2022 Halaman 463 - 469

Research \& Learning in Elementary Education

https://jbasic.org/index.php/basicedu

PAHLAEA

\title{
Pengaruh Tingkat Pendidikan Orang Tua dan Kedisiplinan Siswa Terhadap Minat Belajar di Masa Pandemi
}

\author{
Rusnawati $^{1}$, Perawati Bte Abustang ${ }^{2}$, Syamsul Alam ${ }^{3}$, Cayati $^{4 凶}$ \\ Universitas Megarezky, Indonesia ${ }^{1,2,3,4}$ \\ E-mail: rusnawatiyumna03@gmail.com ${ }^{1}$, andiferawati@gmail.com² ${ }^{2}, \underline{\text { s.alamraja58@gmail.com }}$, \\ cayatijepot@gmail.com ${ }^{4}$
}

\begin{abstract}
Abstrak
Penelitian ini bertujuan untuk mengetahui pengaruh tingkat pendidikan orang tua dan disiplin siswa terhadap minat belajar pada masa pandemi SD Inpres Sarroangin. Jenis penelitian adalah Ex Post Facto dengan pendekatan kuantitatif. Penelitian dilaksanakan di SD Inpres Sarroangin. Sampel penelitian yaitu seluruh siswa kelas V SD Inpres Sarroangin yang berjumlah 35 siswa. Jumlah sampel sebanyak 35 siswa dengan teknik simple random sampling.Hasil penelitian ini menggunakan analisis statistik deskriptif dengan nilai rata-rata tingkat pendidikan orang tua (ayah) 52,86 berada pada kategori SLTP 9 orang dan ibu adalah 65,14 yang berada di SLTA 10 orang. Disiplin siswa dengan nilai rata-rata 46,3143 termasuk dalam kategori minat sedang. Analisis statistik inferensial, hasil uji normalitas tingkat pendidikan orang tua, disiplin dan minat belajar 0,634 >0,05 (distribusi normal), hasil uji homogenitas tingkat pendidikan orang tua 0,065 dan disiplin siswa 0,018>0,05 (homogen), hasil uji linearitas adalah 0,225 >0,05 (linear) berdasarkan hasil data, sehingga terdapat hubungan linearitas antara tingkat pendidikan orang tua dengan disiplin siswa terhadap minat belajar. Hasil uji hipotesis menunjukkan nilai sig 0,000 , dengan sig cretaria $(0,000)<(0,05)$. Kesimpulan dari penelitian ini adalah ada pengaruh tingkat pendidikan orang tua dan disiplin siswa terhadap minat belajar di masa pandemi SD Inpres Sarroangin.
\end{abstract}

Kata Kunci: Tingkat Pendidikan Orang Tua, Disiplin Siswa, Minat Belajar

\begin{abstract}
The research aimed to know the influence of parents' education level and student discipline on interest learning during pandemic at SD Inpres Sarroangin This type Ex Post Facto with quantitative approach. This research was held at SD Inpres Sarroangin. The samples of this research were all students of class V SD Inpres Sarroangin that consisted of 35 students. The total number of samples was 35 students with simple random sampling. The result of this research used descriptive statistic analysis with average education level (father) was 52.86 in the junior high school category 9 people and mother 65.14 in high school 10 people. Discipline with an average of 46.314 in a moderately interesting category. Inferential statistical analysis, normality test results of parents' education level, discipline and interest in learning $0.634>0.05$ (normal distribution), the result of homogeneity test of parents' education 0.065 and students' discipline $0.018>0.05$ (homogeneous), linearity test was $0.225>0.05$ (linearity) based result data, linearity correlation between parents' education level and student discipline on interest in learning. Hypothesis test showed sig value 0.000, sig criteria (0.000) $<\alpha(0.05)$. The conclusion of this research was the influence of parents' education level and student discipline in learning during the pandemic SD Inpres Sarroangin.
\end{abstract}

Keywords: Parents' Education level, Students' Discipline, Learning Interest

Copyright (c) 2022 Rusnawati, Perawati Bte Abustang, Syamsul Alam, Cayati

$\triangle$ Corresponding author :

Email: cayatijepot@gmail.com

DOI : https://doi.org/10.31004/basicedu.v6i1.1980

ISSN 2580-3735 (Media Cetak)

ISSN 2580-1147 (Media Online)

Jurnal Basicedu Vol 6 No 1 Tahun 2022

p-ISSN 2580-3735 e-ISSN 2580-1147 
464 Pengaruh Tingkat Pendidikan Orang Tua dan Kedisiplinan Siswa Terhadap Minat Belajar di Masa Pandemi - Rusnawati, Perawati Bte Abustang, Syamsul Alam, Cayati

DOI: https://doi.org/10.31004/basicedu.v6i1.1980

\section{PENDAHULUAN}

(Helmawati, 2016) Salah satu faktor dasar yang mempengaruhi minat belajar anak adalah ingkat pendidikan orang tua karena tingkat pendidikan orang tua mempengaruhi cara orang tua dalam mengarahkan minat anak dalam belajar. Makin tinggi pengalaman pendidikan, ilmu pengetahuan yang dimiliki, informasi yang diperoleh dan tingkat pendidikan orang tua akan makin mudah dan terbuka wawasannya dalam membimbing danmengarahkan anaknya untuk melanjutkan studi, dalam hal ini dari sekolah dasar menuju ke jenjang yang lebih tinggi SMP, SMA dan perguruan tinggi.

(Abustang, Perawati Bte, 2018) pendidikan yang mampu mendukung pembangunan dimasa mendatang adalah pendidikan yang mampu mengembangkan potensi peserta didik, sehingga mampu menghadapi dan memecahkan problema kehidupan yang dihadapinya. Pentingnya pendidikan bagi suatu negara itu adalah apabila negara itu maju maka warga negaranya juga akan maju.Pendidikan berperan sangat penting dalam pembinaan dan pengembangan potensi manusia.Pembinaan dalam artian pendidikan membentuk sikap, mental dan perilaku peserta didik, untuk mempertahankan sikap mental dan perilaku tersebut peserta didik dapat menjalankannya melalui kedisiplinan.

Minat belajar adalah salah satu faktor yang sangat penting untuk keberhasilan belajar yang dimiliki siswa, minat muncul dari dalam diri siswa itu sendiri. Faktor dari luar minat belajar yaitubagaimana cara guru tersebut mengajar. Peran guru sangat penting untuk menumbuhkan minat belajar siswa salah satunya dengan cara mengajaryang menyenangkan, memberikan motivasi yang membangun (Yunitasari \& Hanifah, 2020).

Minat belajar juga didefinisikan sebagai keinginan dan keterlibatan yang disengaja dalam aktivitas kognitif yang memainkan bagian penting dalam proses pembelajaran, menentukan bagian apa yang kita pilih untuk belajar, dan seberapa baik kita mempelajari informasi yang diberikan, (Slameto, 2017). Semakin kuat atau dekat hubungan tersebut, semakin besar minat.Minat besar pengaruhnya terhadap belajar karena bila bahan pelajaran yang dipelajari tidak sesuai dengan minat siswa, siswa tidak akan belajar dengan sebaik-baiknya, karena tidak adanya daya tarik baginya, ini berarti bahwa keberhasilan belajar siswa sangat ditunjang oleh minat belajar.

(Yohana, n.d.)Tingkat pendidikan orang tua berperan besar dalam membimbing anak agar memiliki prestasi yang baik, karena pendidikan awal diperoleh dari lingkungan keluarga. Hal inilah yang menjadi latar belakang tingkat pendidikan orang tua menjadi salah satu faktor yang mempengaruhi orang tua dalam membimbing dan mengarahkan anaknya dalam hal pendidikan yangakan ditempuh oleh anaknya.Tingkat pendidikan orang tua yang rendah akan cenderung sempit wawasannya terhadap pendidikan, lulus sekolah menengah sudah dirasa cukup. Tingkat pendidikan orang tua yang tinggi akan lebih luas wawasannya terhadap pendidikan. Mereka akan mengarahkan dan membimbing anaknya untuk terus menambah ilmu sehingga anak tersebut mempunyai minat untuk melanjutkan studi, dalam hal ini adalah ke perguruan tinggi.

Berdasarkan hasil penelitian di SD Inpres Sarroangin Kecamatan Bungaya Kabupaten Gowa pada Sabtu 20 Maret 2021 orang tua sangat berperan penting dalam proses pendidikan anaknya, dimana pada masa pandemi covid-19 pembelajaran dilakukan dalam jaringan (Daring) yang juga menambah beban orang tua dikarenakan lokasi perkampungan yang susah dengan jaringan internet. Jadi untuk meningkatkan minat belajar tingkat pendidikan orang tua berperan penting dalam pembelajaran pada anaknya.

\section{METODE PENELITIAN}

Penelitian ini merupakan jenis penelitian ex post facto.Bentuk penelitian ini dipilih karena variabelvariabel bebasnya tidak dikendalikan, dalam arti variabel tersebut sudah terjadi.Jenis penelitian ex post facto menggunakan metode penelitian kuantitatif. Metode penelitian kuantitatif dapat diartikan sebagai metode penelitian yang berlandaskan pada filsafat positivisme, digunakan untuk meneliti pada populasi atau sampel 
465 Pengaruh Tingkat Pendidikan Orang Tua dan Kedisiplinan Siswa Terhadap Minat Belajar di Masa Pandemi - Rusnawati, Perawati Bte Abustang, Syamsul Alam, Cayati

DOI: https://doi.org/10.31004/basicedu.v6i1.1980

tertentu, pengumpulan data menggunakan instrumen penelitian, analisis data bersifat statistik, dengan tujuan untuk menguji hipotesis yang telah diterapkan.

Penelitan ini dilakukan pada bulan bulan Mei 2021 semester genap tahun ajaran 2020/2021 di SD Inpres Sarroangin Kecamatan Bungaya Kabupaten Gowa.Populasi pada penelitian ini adalah seluruh siswa kelas IV, V dan VI SD Inpres Sarroangin Kecamatan Bungaya Kabupaten Gowa, sebanyak 55 siswa. Menurut (Sugiyono, 2019) sampel ialah sebagian kecil dari jumlah dan karakteristik yang dipunyai oleh populasi tersebut. Karena populasi dalam penelitian ini sebanyak 55 siswa dan termasuk kategori banyak, maka penelitian tidak memakai populasi namun menggunakan sampel.Maka penetapan sampel pada penelitian ini sebanyak 35 orang siswa yang terdiri dari 16 siswa laki-laki dan 19 siswa perempuan.Teknik pengambilan sampel pada penelitian ini menggunakan teknik Simple Random Sampling. Simple Random Sampling merupakan teknik pengambilan sampel yang digunakan dengan cara acak tanpa memperhatikan karakteristik, strata yang terdapat dalam populasi tersebut. Teknik pengambilan sampel sederhana yang jumlah keseluruhan populasi 68 siswa, namun peneliti mengambil sampel dengan jumlah 35 siswa. Pengumpulan data dilakukan dengan menggunakan angket tingkat pendidikan orang tua, kedisiplinan siswa dan minat belajar yang dibagikan kepada 35 siswa kelas V SD Inpres Sarroangin.

\section{HASIL DAN PEMBAHASAN}

Penelitian ini dilakukan di SD Inpres Sarroangin Kecamatan Bungaya Kabupaten Gowa. Penelitian ini dilakukan berdasarkan hasil observasi di SD Inpres Sarroangin ditemukan bahwa minat belajar siswa masih kurang walaupun dalam pelaksanaan Kurikulum 2013 sudah menekankan pembentukan karakter siswa.

Pendidikan merupakan suatu proses interaksi manusia dengan lingkungannya yang berlangsung secara sadar dan terencana dalam rangka pengembangan segala potensinya, baik jasmani (kesehatan fisik) dan rohani (pikir, rasa, karsa, karya, cipta, dan budi nurani) yang menimbulkan perubahan positif dan kemajuan, baik kognitif, afektif, maupun psikomotorik yang berlangsung secara terus menerus guna mencapai tujuan hidupnya, (Pratiwi, 2020).

Pendidikan ditempuh dengan proses pembelajaran dengan melakukan kegiatan berupa adanya interaksiyang terjadi diantara guru dan peserta didik selama pemberian materi dikelas berlangsung. Hal ini berlaku untuk pembelajaran yang diberikan mulai dari anak usia dini sampai pada pelajar tingkat perguruan tinggi. Dari kegiatan inilah keberhasilan siswa dalam pencapaian tujuan pendidikan mereka ditentukan. Selain itu, adanya proses pembelajaran yang terjadi juga dapat dilihat dari adanya perubahan dimana siswa menjadi tau akan sesuatu yang baru dan mahir akan keterampilan yang baru atau semakin paham dan mahir akan pengetahuan yang sebelumnya ia miliki (Marwanto, 2021).

(Puspitasari, 2016) berpendapat pendidikan memiliki peran penting dalam peningkatan kualitas suatu bangsa. Keterpaduan pendidikan baik dikeluarga, sekolah dan masyarakat sangat menentukan dalam pendidikan dunia.Pendidikan merupakan suatu proses interaksi manusia dengan lingkungannya yang berlangsung secara sadar dan terencana dalam rangka pengembangan segala potensinya, baik jasmani (kesehatan fisik) dan rohani (pikir, rasa, karsa, karya, cipta, dan budi nurani) yang menimbulkan perubahan positif dan kemajuan, baik kognitif, afektif, maupun psikomotorik yang berlangsung secara terus menerus guna mencapai tujuan hidupnya.

Lingkungan keluarga (orang tua) merupakan pusat pendidikan pertama bagi seorang anak. Keluarga merupakan proses penentu dalam keberhasilan belajar. Orang tua sebagai pendidik pertama karena orang tualah yang pertama mendidik anaknya sejak dan sebagai pendidikan yang utama karena pendidikan yang diberikan orang tua dasar dan sangat menentukan perkembangan anak selanjutnya (Zulnuraini et al., 2014).

Orang tua adalah guru pertama bagi anak-anaknya, namun jika anak masuk sekolah, orang tua yang sebagai mitra kerja yang utama bagi guru anaknya. Bahkan sebagai orang tua, mereka mempunyai berbagai peran yaitu orang tua sebagai pelajar, relevan, pembuat keputusan, anggota tim kerja sama antara guru dan orang 
466 Pengaruh Tingkat Pendidikan Orang Tua dan Kedisiplinan Siswa Terhadap Minat Belajar di Masa Pandemi - Rusnawati, Perawati Bte Abustang, Syamsul Alam, Cayati

DOI: https://doi.org/10.31004/basicedu.v6i1.1980

tua. Dalam peranan tersebut orang tua membantu meningkatkan perkembangan dan pertumbuhan anaknya. (Siagian, 2021)

Di dalam sebuah keluarga peran orang tua sangat penting bagi anak, terlebih lagi ketika anak memasuki usia sekolah dan usia menempuh pendidikan. Keluarga juga dipandang sebagai institusi (lembaga) yang dapat memenuhi kebutuhan insan (manusiawi), terutama kebutuhan bagi perkembangan kepribadiannya dan pengembangan ras manusia. (Siagian, 2021)

Tingkat pendidikan orang tua yang rendah akan cenderung sempit wawasannya terhadap pendidikan, lulus sekolah menengah sudah dirasa cukup. Sedangkan tingkat pendidikan orang tua yang tinggi akan lebih luas wawasannya terhadap pendidikan. Mereka akan mengarahkan dan membimbing anaknya untuk terus menambah ilmu sehingga anak tersebut mempunyai minat untuk melanjutkan studi, dalam hal ini adalah ke perguruan tinggi.

(Anwar, 2020) menyatakan perhatian orang tua merupakan salah satu faktor yang berasal dari luar individu yang dianggap penting. Perhatian orang tua terhadap anak-anaknya dapat dilihat seperti : kasih sayang, bimbingan, didikan, disiplin dan motivasi yang diberikan orang tua terhadap anak-anaknya.

(Mainah, 2018) indikasi dari orang tua yang baik adalah orang tua yang memperhatikan perkembangan anaknya, salah satunya yaitu dengan memberikan perhatian kepada anak dalam proses belajarnya, baik saat dirumah maupun disekolah.

Perbedaan cara pandang pendidikan atas anak dari satu orang tua dengan orang tua lainnya disebabkan oleh cara berpikir dan pendidikan orang tua yang masih rendah seperti orang tua yang berpendidikan hanya tamatan SD, SMP dan SMA dibandingkan orang tua yang tamatan sarjana. Orang tua baik ayah ataupun ibu haruslah memiliki sebuah persamaan keyakinan didalam mendidik anak mereka dikarenakan bapak maupun ibu mempunyai hak dan kewajiban yang sama dalam mendidik anak serta berperan penting pada pertumbuhan dan perkembangan anak. Orang tua yang memiliki pengalaman akan menjadikan anak menjadi pintar dikarenakan orang tua membantu serta mengarahkan anak mereka dalam belajar. (Fadhilaturrahmi, F., Ananda, R., 2021)

Kepribadian anak seharusnya dibangun sejak usia sekolah dasar, salah satu faktor pembentuk kepribadian anak yaitu sikap disiplin karena dengan perilaku disiplin, anak diharapakan dapat melakukan suatu aktivitas secara tertib dan bertanggungjawab (Safitri et al., 2012).

Kedisiplinan merupakan aspek individu yang mengarahkan pada sikap untuk mentaati apa yang diharapkan lingkungannya, baik lingkungan keluarga, sekolah dan masyarakat. Dalam lingkungan keluarga kedisiplinan yang dimaksud yaitu dengan mentaati peraturan yang telah dibuat oleh keluarga. Dalam lingkungan sekolah kedisiplinan yang dimaksud yaitu dengan mentaati peraturan yang telah dibuat lingkungan sekolah, sedangkan dalam lingkungan masyarakat kedisiplinan yang dimaksud yaitu dengan mentaati peraturan yang telah dibuat oleh masyarakat (Wirantasa, 2017).

(Rusmiati, 2017) mengatakan minat belajar adalah suatu proses perubahan di dalam kepribadian manusia dan perubahan tersebut ditampakkan dalam bentuk peningkatan kualitas dan kuantitas tingkah laku seperti peningkatan kecakapan, pengetahuan sikap, kebiasaan, pemahaman, keterampilan, daya fikir serta kemamuankemampuan lain. Berdasarkan pengertian minat sebagaimana tersebut dapat disimpulkan bahwa minat adalah perasaan yang mendorong seseorang untuk melakukan suatu kegiatan atau dorongan yang melatar belakangi seseorang melakukan sesuatu. Oleh karena itu disimpulkan bahwa minat belajar adalah dorongan yang dimiliki seseorang untuk melakukan kegiatan belajar.

Minat ini (interest) adalah kecenderungan untuk selalu memperhatikan dan mengingat sesuatu secara terus menerus. Minat ini erat kaitannya dengan perasaan senang, karena itu akan dikatakan minat itu terjadi karena sikap senang kepada sesuatu. (Nada Naviana Simartama, Naniek Sulistya Wardani, 2019).

(Susanto, n.d.)menyatakan bahwa perkembangan minat siswa tergantung pada kesempatan belajar yang dimiliki oleh seseorang. Hal tersebut dapat diartikan sebagai suatu kesukaan, kegemaran atau kesenangan akan sesuatu. Dengan kata lain bahwa perkembangan minat sangat tergantung pada lingkungan dan orang-orang 
dewasa yang erat pergaulannya dengan mereka, sehingga secara langsung akan berpengaruh pula terhadap kematangan psikologinya.Di era globalisasi mendapatkan informasi sangatlah mudah. Baik itu informasi dalam negeri ataupun luar negeri, gaya hidup, menghilangkan batas-batas negara sehingga kebudayaan satu dengan yang lain dapat dikenal diseluruh dunia. Hal inilah yang memunculkan banyak dampak positif dan negatif dari pesatnya persebaran inforamasi. Pengaruh negatif yang ditimbulkan akan menyebabkan perilaku yang kurang baik bagi anak-anak, terutama siswa sekolah dasar (SD). Perilaku yang kurang baik tersebut dapat menyebabkan siswa menjadi malas belajar, lebih mementingkan nonton youtube dan bermain game daripada belajar. Hal ini akan berdampak pada hasil belajar siswa.

(Muarifah Siti, Shodiqin Ali, 2017) menyatakan bahwa minat memberikan pengaruh positif terhadap pembelajaran akademik. Berbeda dengan motivasi sebagai faktor pendorong pengetahuan, minat tidak hanya sebagai faktor pengetahuan namun juga sebagai pendorong sikap.

Adanya virus covid 19 pada tahun 2020 memberikan dampak yang luar biasa hampir pada semua bidang, salah satunya pada bisang pendidikan. Dengan adanya virus covid 19 ini membuat proses pembelajaran menjadi berubah dari yang tatap muka menjadi pembelajaran jarak jauh, tetapi dalam keadaan seperti ini guru masih melaksanakan kewajibannya sebagai pengajar, dimana guru harus memastikan siswa dapat memperoleh informasi/ilmu pengetahuan untuk diberikan kepada siswa (Yunitasari \& Hanifah, 2020).

Model pembelajaran daring adalah model atau pola pembelajaran pilihan guru untuk merencanakan proses belajar yang sesuai dan efisien guna mencapai tujuan pembelajaran dengan memanfaatkan jaringan komputer dan internet. Model pembelajaran ini juga perlu dirancang dengan baik agar pengalaman belajar peserta didik itu berkesan dan juga dapat mencapai tujuan pembelajaran.

Berikut adalah pengujian normalitas setelah dilakukan penelitian dapat dilihat pada tabel 1.

Tabel 1

Hasil Uji Normalitas

\begin{tabular}{llr}
\hline \multicolumn{3}{c}{ One-Sample Kolmogrov-Smirnov Test } \\
\hline $\mathrm{N}$ & \multicolumn{2}{c}{$\begin{array}{c}\text { Unstandardized } \\
\text { Residual }\end{array}$} \\
\hline Normal Parameters & & 35 \\
\hline Most Extreme Differences & Mean & .0000000 \\
\cline { 2 - 3 } & Std.Deviation3.39832109 & .126 \\
\cline { 2 - 3 } & Absolute & .075 \\
\cline { 2 - 3 } & Positive & -126 \\
\hline Kolmogorov-Smirnov Z & Negative & .746 \\
\hline Asymp. Sig. (2-tailed) & & .634 \\
\hline a. Test distribution is Normal. & & \\
b. Calculated from data. & & \\
\hline Sumber: Data Primer yang telah dioleh & & \\
\hline
\end{tabular}

Sumber: Data Primer yang telah dioleh

Berdasarkan tabel 1, dapat diketahui bahwa ternyata hasil pengujian untuk normalitas akhir dapat dilihat dari nilai Kolmogorov-Smirnov sig. Sebesar 0,634 > 0,05 dapat dikatakan bahwa data dalam penelitian ini telah berdistribusi normal.

Uji Linearitas dilakukan untuk mengetahui apakah variabel bebas dan terikat memiliki hubungan yang linear atau tidak. Uji linearitas dilakukan menggunakan deviation from linearity dengan bantuan program komputer SPSS versi 21.Hasil pengujian linearitas dapat dilihat pada tabel 2. 
Tabel 2

Hasil Pengujian Linearitas

\begin{tabular}{|c|c|c|c|c|c|c|c|}
\hline \multicolumn{8}{|c|}{ ANOVA Table } \\
\hline $\begin{array}{c}\text { Sum of } \\
\text { Squares }\end{array}$ & $\begin{array}{l}\text { Mean } \\
\text { Square }\end{array}$ & Sig. & & & & & \\
\hline \multirow{5}{*}{$\begin{array}{l}\text { Minat } \\
\text { Belajar* } \\
\text { Tingkat } \\
\text { Pendidikan } \\
\text { Orang Tua }\end{array}$} & Between & (Combined & 247.536 & 10 & 24.754 & 1.342 & .274 \\
\hline & Groups & Linearity & 4.338 & 1 & 4.338 & .232 & .634 \\
\hline & & $\begin{array}{l}\text { Deviation from } \\
\text { Linearity }\end{array}$ & 243.198 & 9 & 27.002 & 1.445 & .225 \\
\hline & Within $\mathrm{Gr}$ & ups & 448.750 & 24 & 18.698 & & \\
\hline & Total & & 696.286 & 34 & & & \\
\hline
\end{tabular}

Sumber: Data Primer yang telah diolah

Didalam hasil uji normalitas tingkat pendidikan orang tua 0.634 , kedisiplinan siswa 0.634 dan minat belajar $0.634>0,05$ (berdistribusi normal), hasil uji homogenitas tingkat pendidikan orang tua 0.065 dan Kedisiplinan siswa adalah $0.018>0,05$ (homogen), hasil uji linearitas adalah $0.225>0,05$ (linear), hasil uji hipotesis menunjukkan nilai sig 0.000 , dengan kriteria $\operatorname{Sig}(0.000)<\alpha(0,05)$ dengan demikian secara bersamasama terdapat pengaruh tingkat pendidikan orang tua dan kedisiplinan terhadap minat belajar siswa kelas V SD Inpres Sarroangin Kecamatan Bungaya Kabupaten Gowa.

Hasil penelitian membuktikan adanya pengaruh tingkat pendidikan orang tua terhadap minat belajar siswa. Di kelas V SD Inpres Sarroangin ini yang memiliki orang tua tidak berpendidikan lebih banyak dari siswa yang memiliki orang tua berpendidikan, maka dari itu selama pendidikan daring dilaksanakan banyak siswa yang malas untuk belajar.

\section{KESIMPULAN}

Berdasarkan hasil analisis data baik secara deskriptif maupun inferensial dan pembahasan hasil penelitian maka penulis dapat mengemukakan kesimpulan bahwa gambaran tingkat pendidikan orang tua berada pada kategori SMP, sikap disiplin berada pada kategori cukup disiplin dan minat belajar berada pada kategori cukup berminat.Sehingga terdapat pengaruh tingkat pendidikan orang tua dan kedisiplinan siswa terhadap minat belajar siswa di SD Inpres Sarroangin Kecamatan Bungaya Kabupaten Gowa.

\section{UCAPAN TERIMA KASIH}

Ucapan terima kasih diberikan kepada Basicedu yang telah menelaah dan mereview naskah jurnal dari penulis.

\section{DAFTAR PUSTAKA}

Abustang, Perawati Bte, D. (2018). Pengantar Pendidikan.

Anwar, A. S. (2020). Pengaruh Kedisiplinan, Perhatian Orang Tua dan Minat terhadap Hasil Belajar Matematika. Jurnal Education, 7(1), 32-44.

Fadhilaturrahmi, F., Ananda, R., \& Y. (2021). Persepsi guru sekolah dasar terhadap pembelajaran jarak jauh di masa pandemi covid 19. Jurnal Baicedu.

Helmawati. (20016). Pendidikan Keluarga. PT Remaja Rosda Karya.

Mainah, J. (2018). Pengaruh Perhatian Orang Tua Dan Motivasi Belajar Terhadap Hasil Belajar Akidah Akhlak Siswa M.Ts. Tabiyatul Ulum wedung Demak Tahun Pelajaran 2017/2018. Advanced Optical Materials, 10(1), 1-9.

Marwanto, A. (2021). Pembelajaran pada Anak Sekolah Dasar di Masa Pandemi Covid 19. Jurnal Basicedu, 5(4), 2097-2105. https://doi.org/10.31004/basicedu.v5i4.1128 
469 Pengaruh Tingkat Pendidikan Orang Tua dan Kedisiplinan Siswa Terhadap Minat Belajar di Masa Pandemi - Rusnawati, Perawati Bte Abustang, Syamsul Alam, Cayati

DOI: https://doi.org/10.31004/basicedu.v6i1.1980

Muarifah Siti, Shodiqin Ali, L. I. (2017). Analisis Minat Belajar Siswa dalam Proses Pemebelajaran Tematik Kelas IV SD Negeri Magunrejo 01 Demak. Journal of Chemical Information and Modeling, 53(9), 2125. http://www.elsevier.com/locate/scp

Nada Naviana Simartama, Naniek Sulistya Wardani, T. P. (2019). Jurnal basicedu. Jurnal Basicedu, 3(1), 194199.

Pratiwi, G. F. (2020). Pengaruh Kedisiplinan dan Motivasi Belajar Siswa Saat Pandemi Covid-19 Terhadap Hasil Belajar Ilmu Pengetahuan Alam pada Siswa Kelas VIII SMP Negeri 2 Getasan Tahun Pelajaran 2019/2020.

Puspitasari, R. P. (2016). Hubungan tingkat pendidikan orang tua dengan hasil belajar siswa SD kelas III seGugus I Kecamatan Kampak Kabupaten Trenggalek__Risky Priliani Puspitasari - Repositori Universitas Negeri Malang (p. 2).

Rusmiati. (2017). Pengaruh minat belajar terhadap prestasi belajar bidang studi ekonomi siswa MA Al Fattah Sumbermulyo. Jurnal Ilmiah Pendidikan Dan Ekonomi, 1(1), 21-36.

Safitri, D., Keguruan, F., Ilmu, D. A. N., \& Surakarta, U. M. (2012). Terhadap Prestasi Belajar Matematika Siswa Kelas V Sd Muhammadiyah 3. Pengaruh Kedisiplinan Dan Minat Belajar Terhadap Prestasi Belajar, 3(2).

Siagian, G. (2021). Jurnal basicedu. Jurnal Basicedu, 5(3), 1683-1688.

Slameto. (2017). Teori- Teori Belajar Dan Faktor-Faktor Yang Mempengaruhi. Rineka Cipta.

Sugiyono. (2019). Metode Penelitian Kuantutatif Dan R\&D (Bandung). ALFABETA.

Susanto, A. (n.d.). Teori Belajar Dan Pembelajaran Di Sekolah Dasar Edisi Ke Dua. Prenada Media Group.

Wirantasa, U. (2017). Pengaruh Kedisiplinan Siswa Terhadap Prestasi Belajar Matematika. Formatif: Jurnal Ilmiah Pendidikan MIPA, 7(1), 83-95. https://doi.org/10.30998/formatif.v7i1.1272

Yohana, D. A. (n.d.). Pengaruh tingkat pendidikan orang tua, perhatian orang tua dan motivasi belajar terhadap prestasi belajar siswa _ studi kasus pada kelas III SLTPN I Trimurjo Lampung Tengah - USD Repository. Universitas Sanata Dharma.

Yunitasari, R., \& Hanifah, U. (2020). Pengaruh Pembelajaran Daring terhadap Minat Belajar Siswa pada Masa COVID 19. Edukatif: Jurnal Ilmu Pendidikan, 2(3), 232-243. https://doi.org/10.31004/edukatif.v2i3.142

Zulnuraini, Herlina, \& Sri, R. (2014). Pengaruh Tingkat Pendidikan Orang Tua Terhadap Prestasi Belajar Siswa. Elementary School of Education, 2, 82-93. 